medRxiv preprint doi: https://doi.org/10.1101/2021.09.15.21263338; this version posted September 22, 2021. The copyright holder for this preprint (which was not certified by peer review) is the author/funder, who has granted medRxiv a license to display the preprint in perpetuity.

It is made available under a CC-BY-NC-ND 4.0 International license .

\title{
Efficacy of SARS-CoV-2 wastewater surveillance for detection of COVID-19 at a residential private college
}

Michelle Landstrom ${ }^{1}$, Evan Braun ${ }^{1}$, Ellen Larson ${ }^{2}$, Merrill Miller ${ }^{2}$, and Geoffrey H. Holm ${ }^{1 *}$

${ }^{1}$ Department of Biology, and ${ }^{2}$ Student Health Services, Colgate University, 13 Oak Dr., Hamilton, NY, 13346

${ }^{*}$ Corresponding Author. Email address: gholm@colgate.edu

Keywords: SARS-CoV-2, COVID-19, wastewater surveillance, sewershed, residential college

Abstract.

Many colleges and universities utilized wastewater surveillance testing for SARS-CoV-2 RNA as a tool to help monitor and mitigate the COVID-19 pandemic on campuses across the United States during the 2020-2021 academic year. We sought to assess the efficacy of one such program by analyzing wastewater RNA load data in relation to SARS-CoV-2 cases identified through individual surveillance testing. Almost $80 \%$ of the cases on campus were associated with positive wastewater tests, resulting in an overall positive predictive value of $\sim 79 \%$ (Chi square 48.1, $\mathrm{Df}=1, p<0.001$ ). However, half of the positive wastewater samples occurred in the two weeks following the return of a student to the residence hall following isolation, and therefore were not useful in predicting new infections. When these samples were excluded, the positive predictive value of a positive wastewater sample was $\sim 54 \%$. Overall, we conclude that the continued shedding of viral RNA by patients past the time of potential transmission confounds the identification of new cases using wastewater surveillance, and decreases its effectiveness in managing SARS-CoV-2 infections on a residential college campus.

\section{Introduction.}

The severe acute respiratory syndrome coronavirus 2 (SARS-CoV-2) pandemic clearly poses significant challenges for many economic sectors. Prior to the introduction of vaccines, and even post-introduction, many businesses and institutions that rely on in-person meetings struggled to identify best practices that could allow for continued operation. In some instances, especially during government-mandated "lockdowns," institutions transitioned to remote 
medRxiv preprint doi: https://doi.org/10.1101/2021.09.15.21263338; this version posted September 22, 2021. The copyright holder for this

It is made available under a CC-BY-NC-ND 4.0 International license .

operations. However, in many cases, remote operation was either not sustainable or failed to deliver satisfactory outcomes, leading these institutions to consider means for returning to inperson operation. These challenges continue to be felt acutely among institutions of higher education, particularly those with a sizeable residential component, as the high population density of dormitories, especially those with shared bathroom facilities, create conditions that can facilitate rapid transmission of respiratory pathogens.

As data emerged that SARS-CoV-2 can infect cells in the gastrointestinal tract $(1,2)$, and that SARS-CoV-2 RNA can be detected in patient stool $(3,4)$, including from patients prior to the onset of clinical symptoms (5), many groups began investigating whether detection of SARSCoV-2 RNA in wastewater could be used as a means of monitoring communities for emerging infections, or of directing public health responses. Epidemiological wastewater surveillance had previously been utilized for poliovirus, norovirus, and rotavirus (6-8), and gave strong indication that similar approaches could be beneficial, either to directly assess disease burden in a population, identify areas where the SARS-CoV-2 was newly introduced, or monitor changes in transmission status over time and thereby assess the effects of community interventions (9). The utility of these approaches became even more evident as data emerged correlating levels of SARS-CoV-2 RNA in wastewater with number of cases in the sewershed (10-12), with wastewater RNA levels increasing several days prior to an increase in positive test results indicative of SARS-CoV-2 infections (13-15).

Based on these reports, in the lead up to the Fall 2020 academic semester, many colleges and universities in the U.S. sought to implement wastewater surveillance as a tool to manage the pandemic, either as a means to detect the presence of cases within the campus population, to monitor infection levels on campus, or to target particular residence halls for individual or pooled patient testing to directly identify infected individuals (16-21). Since essentially all of these systems were implemented de novo, there was a lot of variability in how they were set up and used. Some institutions monitored wastewater via campus or municipal wastewater treatment plants, whereas others implemented systems to capture samples from individual residence halls or sewer lines. Some institutions collected samples that were then processed by commercial laboratories, whereas others handled their samples in house. Among 
medRxiv preprint doi: https://doi.org/10.1101/2021.09.15.21263338; this version posted September 22, 2021. The copyright holder for this

It is made available under a CC-BY-NC-ND 4.0 International license .

63 the strategies communicated by various institutions, there was considerable variation in the

64 timing and frequency of collection, and in the number of campus locations that were sampled.

65 Given this variability, it is important to assess the efficacy of the various approaches, to identify

66 best practices and help inform continued development and implementation of wastewater

67 surveillance strategies as a pandemic response (19).

68 In the summer of 2020, we developed and implemented a wastewater surveillance

69 system as one piece of a comprehensive plan to facilitate the return of students to campus

70 residences at Colgate University. Wastewater was assayed via 24-hour composite samples

71 taken 2-3 times weekly at each of seven campus locations (sewer lines or sewage lift stations)

72 and the samples were tested for the presence of SARS-CoV-2 RNA by quantitative reverse-

73 transcriptase PCR (qRT-PCR). Simultaneously, students were regularly tested for SARS-CoV-2

74 infection by anterior nares swabs, using a commercial PCR-based testing provider. We obtained

75 de-identified information on student positive cases, the Ct value of the positive tests, and the

76 time of removal and return to the residence hall for isolation, and analyzed this data with

77 respect to the detection of SARS-CoV-2 in the waste stream. In the fall and spring academic

78 semesters, Colgate identified a total of 107 student cases of SARS-CoV-2 infection. Almost $80 \%$

79 of these cases were associated with positive wastewater tests, resulting in an overall positive

80 predictive value of $\sim 79 \%$. However, half of the positive wastewater samples occurred in the two

81 weeks following the return of a student to the residence hall following isolation. When these

82 samples were excluded, the positive predictive value of a positive wastewater sample was

$83 \sim 54 \%$. Overall, we conclude that the continued shedding of viral RNA by patients past the time

84 of potential transmission confounds the identification of new cases using wastewater

85 surveillance, and decreases its effectiveness in managing SARS-CoV-2 infections on a residential

86 college campus.

87

88 Materials and Methods.

89 Study site. Colgate University is a private residential undergraduate college with around 3,000

90 students, situated in the rural community of Hamilton, NY (population 3,800). For the 2020 -

912021 academic year, students had the choice of remote or in-person instruction, and over 2,600 
medRxiv preprint doi: https://doi.org/10.1101/2021.09.15.21263338; this version posted September 22, 2021. The copyright holder for this

preprint (which was not certified by peer review) is the author/funder, who has granted medRxiv a license to display the preprint in perpetuity.

It is made available under a CC-BY-NC-ND 4.0 International license .

92 students chose to be in residence, with 2,333 students in campus residence halls in the fall

93 semester and 2280 students in campus residence halls in the spring semester (Table 1), and the

94 rest in off-campus (private) housing in the village of Hamilton.

Wastewater sample collection. Wastewater samples were collected at seven locations on the

97 Colgate University campus (Table 1; Fig. 1) using three ISCO GLS compact composite samplers

98 (Teledyne ISCO, Lincoln, NE). Five of the seven locations (GH, SPW, BAE, CD, BC) were in sewer

99 access holes, while two were at lift stations (PL, TH). A $24 \mathrm{~h}$ composite sample (50 ml every 20

$100 \mathrm{~min}$ ) was collected at around 10 AM each weekday, and the samplers were rotated among the

101 collection points at that time, resulting in each collection point being sampled an average of 2.1

102 times per week. Three of the access points $(\mathrm{GH}, \mathrm{BC}$, and $\mathrm{TH})$ required external ground-level

103 storage of the sampler; at these locations, a single draw was obtained during the times when

104 the ambient air temperature was too low to permit composite sampling (intermittently

105 between Jan. and Mar.). Composite samples were mixed by agitation and $\sim 250 \mathrm{ml}$ of the total

106 volume of each sample was collected and returned to the lab, where it was stored at $4^{\circ} \mathrm{C}$ until

107 processing. The interior tubing of the samplers was rinsed with $10 \%$ bleach followed by distilled

108 water after each sample collection. Dedicated collection hoses and filters remained at each

109 location and were rinsed with distilled water after each collection and with $10 \%$ bleach on a

110 regular basis. Samples were also collected from the Village of Hamilton wastewater treatment

111 plant, though these samples were excluded from this analysis since infection data from the

112 entire population serviced by this facility (which includes Colgate University and Colgate's

113 isolation space) was not available.

115 Ultracentrifugation and RNA extraction. RNA was extracted following the method of Wilder et 116 al. 2021 (22). All steps prior to RNA extraction were conducted in BSL2 conditions, as approved

117 by the Colgate University Institutional Biosafety Committee. Briefly, $26 \mathrm{ml}$ of composite

118 sample was layered over $12 \mathrm{ml}$ of sucrose cushion ( $50 \%$ sucrose in $20 \mathrm{mM}$ Tris- $\mathrm{HCl}(\mathrm{pH} 7.0), 100$

$119 \mathrm{mM} \mathrm{NaCl}$, and $2 \mathrm{mM} \mathrm{EDTA}$ ) in a 25×89 mm ultracentrifuge tube (Beckman Coulter, Brea, CA).

120 The samples were then centrifuged in a SW28 Ti rotor (Beckman Coulter) at 150,000 x $g$ in a L7- 
12155 ultracentrifuge (Beckman) for $45 \mathrm{~m}$ at $4{ }^{\circ} \mathrm{C}$. The supernatant was decanted and the pellets

122 were resuspended in $200 \mu \mathrm{l}$ of PBS and transferred to a $1.7 \mathrm{ml}$ microcentrifuge tube. RNA was

123 extracted from the sample either using an AllPrep PowerViral DNA/RNA kit (Qiagen Biosciences)

124 according to manufacturer's protocol (with the omission of the optional bead beating step), or

125 using Trizol (1 ml; Invitrogen/ThermoFisher) according to manufacturer's protocol. Both

126 methods yielded equivalent RNA isolation based on pilot runs using duplicate samples. RNA was

127 eluted in $50 \mu \mathrm{l}$ of RNase-free water and stored (when necessary prior to analysis) at $-80^{\circ} \mathrm{C}$.

128 Samples $(5 \mu \mathrm{l})$ were treated with DNase I (Invitrogen/ThermoFisher) according to the

129 manufacturer's protocol. DNase-treated samples were then directly used for quantitative

130 reverse transcriptase PCR (qRT-PCR).

132 Quantification of relative wastewater SARS-CoV-2 RNA levels. Levels of SARS-CoV-2 RNA in

133 undiluted samples were detected by one-step multiplex TaqMan qRT-PCR, using TaqPath 1-step

134 Multiplex Master Mix (ThermoFisher) according to manufacturer's protocol. SARS-CoV-2 RNA

135 was detected using the 2019-nCoV CDC RUO kit (Integrated DNA Technologies; IDT), containing

136 primers amplifying two regions in the SARS-CoV-2 nucleocapsid (N) gene (N1 and N2). A control

137 plasmid containing the complete nucleocapsid gene from SARS-CoV-2 (IDT), as well as a

138 synthetic SARS-CoV-2 RNA (Applied Biological Materials, Richmond, BC, Canada), were used as

139 positive controls for isolation procedures and for qRT-PCR reactions. To normalize for

140 differences in biological material in each sample, extracted RNA was also probed using TaqMan

141 primers specific for human RNAse P (2019-nCoV CDC RUO primers and probe kit; IDT), and for

142 the crAssphage bacteriophage (22). Initial samples showed a high degree of correlation

143 between RNAse P Ct values and crAssphage Ct values, although crAssphage was not as reliably

144 detected in all samples (not shown). Therefore, RNAse P Ct values were used to normalize

145 SARS-CoV-2 $\mathrm{N}$ gene multiplex Ct values, using the $\Delta \Delta \mathrm{Ct}$ method, to obtain a relative value for

146 SARS-CoV-2 RNA for each sample, which was reported to the Colgate University Health

147 Analytics Team. 
medRxiv preprint doi: https://doi.org/10.1101/2021.09.15.21263338; this version posted September 22, 2021. The copyright holder for this preprint (which was not certified by peer review) is the author/funder, who has granted medRxiv a license to display the preprint in perpetuity.

It is made available under a CC-BY-NC-ND 4.0 International license .

149 Individual SARS-CoV-2 surveillance testing. For both academic semesters, all Colgate University 150 students were required to submit negative results from a home PCR-based SARS-CoV-2 test

151 taken $\sim 7$ days prior to arrival at campus. Students, along with all employees, were then tested 152 using a PCR-based test at the time of student arrival to campus. All students then entered a 153 mandatory 14-day quarantine period. Students were tested a second time $~ 7-9$ days post154 arrival and were not released from quarantine until the results from the second test had been 155 returned. Following quarantine, the whole campus population (students and employees) were 156 randomly selected for surveillance testing at a rate of $6 \%$ of each residence hall/area or campus 157 employee population per week (fall semester), or scheduled for surveillance testing once every 1582 weeks (spring semester). In the fall semester, 50-70 additional students were selected each 159 week for targeted surveillance testing based on wastewater SARS-CoV-2 results, identified 160 positive cases within specific residence halls, or other events indicating increased risk of 161 transmission (bringing the total percentage of the student population tested up to 10\% per 162 week). Targeted surveillance testing was not widely performed during the spring semester, 163 given the increased frequency of baseline surveillance testing. Patient samples were collected 164 from the anterior nares by Colgate University Student Health Services and volunteers, and were 165 shipped to Aegis Biosciences (Nashville, TN) for PCR-based analysis. Ct values for positive tests 166 were reported by Aegis to Colgate University Student Health Services. The average Ct value for 167 two or three PCR reactions using individual primer pairs was calculated for each case and used 168 for analysis. In both semesters, students with symptoms consistent with COVID-19 were 169 diagnostically tested in-house using a rapid PCR-based assay (Cepheid Biosciences). In some 170 cases, patient tests were performed at other local laboratories. Ct values were not available for 171 these test results. Students that tested positive for SARS-CoV-2, and their close contacts, were 172 identified upon receipt of test results (typically 48-72 $\mathrm{h}$ post-collection) and separately isolated 173 or quarantined at a local facility (which was not subject to wastewater surveillance), or, if

174 feasible, at their family home, until allowed to return to their residence hall as established by 175 Madison County Board of Health and New York State guidelines. 
177 Data analysis. Data on positive SARS-CoV-2 test results, their Ct values (if available), and the

178 start and return dates of isolation, devoid of patient-identifying information were obtained

179 from Colgate University Student Health Services. Data on de-identified total residence hall

180 occupancies were obtained from the Office of Institutional Planning and Research. Due to low

181 case numbers in one residence $(\mathrm{GH})$, data from this residence and waste stream was combined

182 with that of BAE to eliminate potentially identifying information. Additionally, specific dates

183 have not been included in the manuscript to also eliminate potentially identifying information.

184 This project was ruled as exempt from the review process by the Colgate University Institutional

185 Review Board. Data was analyzed using GraphPad Prism statistical software package as

186 indicated. For temporal analysis, positive wastewater samples were categorized according to

187 their temporal relationship with positive student case(s), including those that occurred: i)

188 within seven days prior to detection of a positive case; ii) between the date of a positive patient

189 sample and when the student was moved to the isolation facility; iii) between the date a

190 student was moved to the isolation facility and when they returned to the residence; iv) within

1915 days of the student's return from isolation; v) within 6-14 days of the student's return from

192 isolation; and vi) those that did not correspond to any identified case with in those temporal

193 parameters.

Results.

During the spring and summer of 2020, Colgate University engaged in a strategic

197 planning process to determine how best to facilitate the return of students to campus for the

198 2020-2021 academic year, given the challenges associated with the SARS-CoV-2/COVID-19

199 pandemic. At that time, data was emerging regarding the efficacy of detecting the presence of

200 SARS-CoV-2 RNA in wastewater efflux via quantitative reverse transcriptase PCR (qRT-PCR) as a

201 means of population surveillance. SARS-CoV-2 RNA can be detected in the wastewater stream

202 as early as a week prior to identification of patients with COVID-19 based on screening of

203 symptomatic individuals $(13,14)$, and based on this information, we decided to implement

204 wastewater surveillance as one part of a comprehensive plan to facilitate the return of students

205 to campus residences for the academic year. Colleagues at other local academic institutions 
were working on methods to quantify SARS-CoV-2 RNA in wastewater (22) and graciously assisted in developing protocols for wastewater surveillance at Colgate University.

The University purchased three compact composite wastewater samplers and we consulted with the Facilities Department to determine locations for sampling. We identified seven locations on campus that would allow as many student residences as possible to be

211 sampled, while minimizing the overlap with effluent waste from academic and administrative

212 buildings (Fig. 1). However, due to the integrated nature of some administrative spaces within 213 residence halls, it was impossible to exclude these entirely at some of the sampling points. In 214 total, the sampling locations captured waste from thirteen individual residence halls or 215 residential complexes, which housed approximately $73 \%$ of Colgate students living in campus216 owned residences (Table 1). The largest population sampled was a complex with 370 students, 217 while the smallest was a residence with 73 students, with a mean of 242 residents sampled at 218 each collection point. Due to containing potentially identifying information, data from the 219 smallest residence $(\mathrm{GH})$ was combined with that for BAE for analysis. For wastewater samples, 220 the relative level of SARS-CoV-2 RNA was determined using the Ct value of multiplex qRT-PCR 221 reactions targeting the SARS-CoV-2 genome, normalized to the amount of biological material in 222 the sample, as determined by the Ct value of a qRT-PCR reaction to detect human RNase $P$ 223 mRNA.

224 Concurrently, Colgate University engaged in individual surveillance testing of students 225 and employees, as outlined. During the fall semester, from the start of first year arrival in late 226 August, 2020 until most students left campus in mid-November, PCR-based surveillance testing 227 detected 44 cases of SARS-CoV-2 infection in the student population (Table 1; Fig. 2A). Of the 228 fall cases, 36 of the $44(81 \%)$ were detected during the two arrival testing periods, and many of 229 these cases had Ct values of $>35$, suggesting low viral RNA levels. The mean Ct value of the 230 positive tests in the fall was 34.54 (Fig. 3A). Thirty-one of the cases (70.5\%) occurred in 231 residences from which wastewater samples could be collected. In the spring semester, from 232 arrival for most students starting in late January, 2021, through the end of the semester in early 233 May, 63 cases of SARS-CoV-2 infection were detected (Table 1; Fig. 2B). Again, a large number 234 of cases $(28 ; 44 \%)$ were detected during the two arrival testing periods. The mean Ct value of 
medRxiv preprint doi: https://doi.org/10.1101/2021.09.15.21263338; this version posted September 22, 2021. The copyright holder for this

preprint (which was not certified by peer review) is the author/funder, who has granted medRxiv a license to display the preprint in perpetuity.

It is made available under a CC-BY-NC-ND 4.0 International license .

235 the positive tests in the spring was 26.59, which was significantly lower (higher viral RNA levels)

236 than in the fall (Fig. 3A; $p<0.0001$ ). The percentage of cases that occurred in residences from

237 which wastewater samples could be collected (48 of $63 ; 76.2 \%$ ) was not significantly different

238 than in the fall ( $p=0.51$ by Chi-square analysis).

239 In the fall, SARS-CoV-2 RNA was detected in 12 wastewater samples, from 6 out of the 7

240 collection points (Table 1; Fig. 2A). During the spring semester, 48 wastewater samples tested

241 positive for SARS-CoV-2, from all 7 collection points (Table 1; Fig. 2B). The relative level of SARS-

242 CoV-2 RNA detected in wastewater samples was not significantly different between the two

243 semesters (Fig. 3B). We analyzed the data for each wastewater sample location (Fig. 4), plotting

244 the relative wastewater SARS-CoV-2 levels (black circles; left Y-axis); as well as the Ct value of

245 each positive patient sample (red circles; right Y-axis). We also plotted positive patient samples

246 for which no Ct value was available (red stars), as well as the dates the positive cases were

247 moved from the residence hall into the isolation facility (yellow squares) and the dates the

248 cases moved back to the residence hall following isolation (green squares). From these data, we

249 categorized each positive wastewater sample according to its temporal relationship with

250 positive student case(s), as described.

251 Overall, 14 of the positive samples (23.3\%) were collected in the seven days prior to the

252 identification of an infected individual in a residence that contributed to the sampled waste

253 stream, or in the time between when patient specimen was collected and the time the

254 individual moved to quarantine (Fig. 5A). Thirty of the positive samples (50\%) were collected

255 from locations in the two weeks following the return of an individual from isolation into that

256 waste stream. Only two positive samples were collected in the period between when an

257 infected individual was removed to the isolation facility and when they returned to the

258 residence, which could result from lingering biological material in the waste stream. Twelve

259 positive samples (20\%) were not linked temporally with any student cases in that waste stream.

260 There was no significant difference in the relative wastewater SARS-CoV-2 RNA levels in

261 samples from these categories (Fig. 5B; $p=0.2$ by Kruskal-Wallace test). We also analyzed the

262 wastewater results according to the number of student cases identified in the residences 
263 contributing to the waste stream at the time of sample collection. Again, no significant

264 differences were observed (Fig. 5C; $p=0.17$ by Kruskal-Wallace test).

265 A similar analysis was conducted on the Ct values of the patient specimens based on the 266 temporal proximity of positive wastewater samples (Fig. 5D). In this analysis, 21 of the

267 identified student cases in sampled residences (21.5\%) were not linked temporally with any

268 positive wastewater sample. There was a significant difference in Ct values between categories,

269 with significantly higher Ct values (lower viral RNA levels) found in patient samples that were

270 not linked with any positive wastewater samples than in those found in patients in which a

271 positive wastewater sample was detected in the seven days prior to specimen collection $(p<$

2720.001 by Kruskal-Wallace test with Dunn's multiple comparisons).

273 Examining the ability of a positive wastewater test to predict the presence of a case in a

274 residence, we found that 46 positive wastewater samples were collected from residences in

275 which a student case was identified, in the period from 7 days prior to the positive patient

276 sample(s) being collected to 14 days after the student(s) returned to the residence following

277 isolation. In contrast, 12 positive wastewater samples were collected from residences in which

278 no student case was identified (i.e. false positives), resulting in an overall positive predictive

279 value of $\sim 79 \%$ (Table 2; Chi square 48.1, $\mathrm{Df}=1, p<0.001$ ). Out of 350 negative wastewater

280 samples, 120 were collected in the period from 7 days prior to a positive case identification to

28114 days after the student(s) returned to the residence (i.e. false negatives), resulting in an

282 overall negative predictive value of $\sim 66 \%$. From this data, the sensitivity of the wastewater

283 testing was $\sim 28 \%$, while the specificity was $\sim 95 \%$. The fact that many of the positive samples

284 occurred in the 14 day period following students returning to a residence following isolation

285 was not unexpected, as SARS-CoV-2 RNA can be detected in patient stool for several weeks

286 following infection (23). However, this could confound the use of wastewater samples to

287 identify new cases in a residence hall. To assess the predictive capacity for an isolated positive

288 wastewater sample to identify new cases in residence halls with no recent cases, we excluded

289 all samples collected in the 14 days following the return of a student to a residence from the

290 analysis. We identified 14 positive wastewater samples collected in the period 7 days prior to

291 when a positive patient sample was collected, in contrast to 10 negative samples collected in 
292

293

the same period, giving a sensitivity of $\sim 58 \%$ (Table 3; Chi square 64.61 , Df $=1, p<0.001$ ). The positive predictive value of these positive samples, based on the 12 false positive samples, was $\sim 54 \%$, while the negative predictive value was $\sim 96 \%$.

Overall, this data suggests that wastewater testing deployed in this manner can be largely predictive of SARS-CoV-2 infections in college residence halls; however, the analysis of a positive result can be complicated in situations where infected students return to a residence following isolation, as SARS-CoV-2 RNA may continue to be detected in the waste stream for at least two weeks after return.

\section{Discussion.}

Municipal wastewater testing for SARS-CoV-2 RNA can provide a robust indicator of community transmission $(11,13,14)$, and this information can be used to inform public health responses. Many colleges and universities implemented wastewater surveillance testing during the 2020-2021 academic year (19); however, the efficacy of these efforts in identifying infection clusters and leading to mitigation of transmission has not been fully investigated. In this study, we combine data on wastewater SARS-CoV-2 detection from discrete campus residences with information on student cases, including RNA levels and timing of exit and return to the residence following isolation, to provide insight into the efficacy of wastewater surveillance as a public health strategy at a residential undergraduate college. Overall, we found that while around a quarter of positive wastewater samples indicated the presence of SARS-CoV-2infected individuals prior to their identification by individual surveillance testing, half of the positive wastewater samples occurred within 14 days after students returned to residence halls following isolation. The capacity for individuals to continue to shed SARS-CoV-2 RNA in stool past the point of likely transmission potentially limits the utility of wastewater surveillance in a college environment where students leave and return to residences following infection.

Our results are generally concordant with other reports of wastewater surveillance programs on college campuses. Our determined positive predictive value for isolated wastewater positive samples (excluding dormitories with students returning from isolation), of $\sim 54 \%$ is lower than some reported values, such as at the University of Arizona (82\%; (21)), or at 
medRxiv preprint doi: https://doi.org/10.1101/2021.09.15.21263338; this version posted September 22, 2021. The copyright holder for this

preprint (which was not certified by peer review) is the author/funder, who has granted medRxiv a license to display the preprint in perpetuity.

It is made available under a CC-BY-NC-ND 4.0 International license .

321 UC San Diego, where wastewater surveillance allowed for the early diagnosis of $85 \%$ of cases on

322 campus (16). However, these programs operated on a very different scale, with, for example,

323 the UCSD system employing 68 samplers with automated sample processing of daily samples.

324 Similar to other institutions, we could identify single cases in a residence hall from wastewater

325 samples $(17,18)$, although a large number of negative samples from residences with student

326 cases decreased the overall sensitivity. Groups that sampled on a weekly basis concluded that

327 that was too infrequent for effective identification of cases, and suggested that daily testing

328 would be most appropriate (20). We found that our strategy, where most residences were

329 sampled 2-3 times a week, was generally effective while not becoming impractical to manage

330 for a small academic laboratory.

331 We observed significantly higher average Ct values (lower viral RNA levels) among cases

332 in the fall semester than the spring semester (Fig. 3A). This is most likely a reflection of changes

333 in the stringency of the cutoff for the identification of a positive case used by the PCR testing

334 provider that occurred around October 2020. Initially, a positive case was identified by a

335 defined $\mathrm{Ct}$ value of $<40$ in one of two PCR reactions using different primer pairs. Starting in

336 October, a third PCR reaction was added to the protocol, with a positive case identified with a

337 defined $\mathrm{Ct}$ value of $<40$ in at least two of the three reactions. This increased stringency may

338 have helped exclude potential false positives, especially when the positive predictive value of

339 the PCR-based test was low due to low prevalence in the population. These data could also

340 potentially be explained by students having been infected during the summer and continuing to

341 shed low levels of SARS-CoV-2 RNA in their nasopharynx at the time of the arrival tests in

342 August. If this were the case, however, we would have expected the pre-arrival test that

343 students took ahead of coming to campus to identify these individuals. Alternatively, students

344 may have been infected during travel to campus, and therefore have been tested at a time

345 prior to when they reached peak RNA levels. However, if this were the case, we would have

346 expected that positive cases identified in the second round of arrival testing would have lower

347 Ct values (higher RNA levels), which was not observed. Whatever the reason for this difference,

348 it has implications for our wastewater results, as cases with higher Ct values (lower RNA levels)

349 were significantly less likely to be associated with a positive wastewater result (Fig. 5D). 
medRxiv preprint doi: https://doi.org/10.1101/2021.09.15.21263338; this version posted September 22, 2021. The copyright holder for this

preprint (which was not certified by peer review) is the author/funder, who has granted medRxiv a license to display the preprint in perpetuity.

It is made available under a CC-BY-NC-ND 4.0 International license .

We observed no significant difference in the normalized SARS-CoV-2 RNA levels in wastewater based on the proximity of the wastewater sample to when a positive student case was identified (Fig. 5B), or based on the number of cases contributing to the waste stream (Fig. 5C). These results are contrary to other reports, in which wastewater SARS-CoV-2 RNA levels were observed to tightly correlate with case numbers $(13,14)$. We attribute this discrepancy to the relatively small number of people contributing to each waste stream in our study (hundreds vs. several thousand individuals in some municipal sewer sheds), and to the variable and sporadic nature of the flow rate at each sampling location. Composite samples from the lift stations tended to be more consistent than from the sewer access holes, where the flow rate changed dramatically on a minute-by-minute basis, and where the structure of the sewer caused pooling in some lines more than others. This caused marked differences in the amount and density of samples collected, and this variability could potentially lead to differences in the amount of biological material collected between the locations, or between samples from the same location. Additionally, during periods of inclement weather, some sampling locations could only be sampled with a single draw, rather than a 24-hour composite. These factors could therefore impact the relative concentration of SARS-CoV-2 RNA present in each sample, despite the use of RNase P RNA levels to normalize the SARS-CoV-2 RNA levels. Furthermore, the variable flow rate, as well as the lack of equipment to accurately measure this type of flow, made absolute quantification of SARS-CoV-2 genome copies per milliliter, (the standard used by several other studies; $(11,13))$, impossible. We conclude that under these conditions, detection of SARS-CoV-2 RNA in the waste stream should be considered on a positive/negative basis, rather than attempting to use RNA quantification as a predictor of case load or timing.

373 the sample collection points did not only capture waste from student residences. In some cases, 374 other campus buildings contributed to the waste stream (though every effort was made to 375 minimize this), whereas in other cases, the residence halls also house additional administrative 376 or classroom spaces. Additionally, custodial and facilities maintenance staff routinely accessed 377 the buildings and may have contributed to the waste stream at the sampling locations. In one 378 instance in the fall semester, a positive SARS-CoV-2 RNA signal in a wastewater sample was 
medRxiv preprint doi: https://doi.org/10.1101/2021.09.15.21263338; this version posted September 22, 2021. The copyright holder for this preprint (which was not certified by peer review) is the author/funder, who has granted medRxiv a license to display the preprint in perpetuity.

It is made available under a CC-BY-NC-ND 4.0 International license .

379 used to guide targeted PCR-based testing of students in residences, which did not identify any

380 positive student cases. Concurrently, however, an employee that spent time in the space(s)

381 contributing to that waste stream did test positive for SARS-CoV-2 infection, although whether

382 they used restroom facilities in those location(s) is not known. Therefore, it is possible that

383 other positive wastewater samples that did not coincide with a positive case may not be "false

384 positives," per se, but rather reflect other non-residents that contributed to the waste stream.

385 It is also possible that these positive wastewater samples reflect infected students that were

386 not identified by individual surveillance testing, either because they were not tested during

387 their infection or their test results were falsely negative.

388 There are several additional limitations of this study that impact our ability to fully

389 interpret the data. First, students that reported symptoms consistent with COVID-19 were

390 tested using an in-house rapid nucleic acid amplification system that does not provide $\mathrm{Ct}$

391 values. Differences in viral dynamics at the time of testing (in surveillance tests vs. symptomatic

392 testing) could skew our analysis of the Ct values of cases associated with positive wastewater

393 detection of SARS-CoV-2. Second, the nature of our sampling strategy, with the collectors

394 rotating between sampling locations on a two-to-three-day schedule, means that our samples

395 were not evenly spaced, especially around times of arrival testing, when a majority of our

396 positive cases were detected, and around times when students returned to residence halls

397 following isolation. This confounds our analysis of wastewater RNA levels relative to the time of

398 case detection or return, as it meant that some residences may have been sampled the

399 morning after a student returned (potentially leading to a higher level of viral RNA shed into the

400 waste stream), whereas others might not have been sampled until up to $72 \mathrm{~h}$ post-return, when

401 shed RNA levels may have been lower. A sampling protocol that allowed for more continuous

402 monitoring of wastewater RNA levels from residences following a return from isolation may

403 have allowed for a more precise correlation between RNA levels and time from isolation return

404 to be detected. This, however, would require more resources devoted to the project and would

405 be beyond the scope of what our laboratory could handle. Finally, due to infrastructure

406 architecture and geography, only around $73 \%$ of students lived in residences that could be 
407

408

409

410

411

412

413

414

415

416

417

418

419

420

421

422

423

424

425

426

427

428

429

430

431

432

433

434

435

easily monitored via the waste stream. This decreased the overall utility of wastewater surveillance as a means for managing emerging cases on campus.

Overall, based on the data presented here and our lived experience of managing the COVID-19 pandemic during the 2020-2021 academic year at Colgate University, we found that on a practical level, wastewater surveillance had more utility in the fall semester, when a smaller percentage of the community was subject to random PCR-based individual surveillance testing. The wastewater results could then be used to direct additional targeted testing to individual residences with positive wastewater RNA samples, and, with a positive predictive value of $\sim 54 \%$ for an isolated wastewater positive sample, this could be potentially be a more cost- and resource-effective means of detecting new positive cases than large-scale individual student testing. In the spring semester, with approximately half of the students in each residence were tested each week, by the time a positive wastewater sample was detected, it was more practical to wait for the individual surveillance results to become available than to target students in those residences for additional testing. This was further confounded when positive student cases returned to the residences following isolation, making it difficult to distinguish between a new infection and continued SARS-CoV-2 RNA shedding in previouslyinfected individuals. Additionally, the presence of cases in residences in which no wastewater SARS-CoV-2 RNA was detected suggests that wastewater surveillance of this type should not be used as the only means for the detection of cases on campus. As the price of personal surveillance testing, via pooled or individual samples, continues to decrease, we conclude that this should be viewed as a more effective means of controlling SARS-CoV-2 transmission on campus than wastewater testing of individual residence halls.

Authorship contribution statement: G.H.H. initiated the project, developed the wastewater sampling strategy and SARS-CoV-2 RNA detection protocol, contributed to sample collection, analyzed and interpreted the data, and drafted the manuscript; M.L. contributed to sample collection, performed the RNA extraction and qPCR, analyzed the qPCR data, and edited the manuscript; E.B. contributed to sample collection; E.L. and M.M collected and assembled deidentified patient information, and edited the manuscript. 
Declaration of competing interest:

The authors declare that they have no known competing financial interests or personal

440 relationships that could have appeared to influence the work reported in this manuscript.

442 Data availability statement: All data related to this project is available at figshare.com, licensed

443 CC by 4.0

Acknowledgments: The authors wish to thank David Larsen (Syracuse University) and Hyatt

446 Green (SUNY ESF) for their initial input and advice on implementing a wastewater surveillance

447 system. We also wish to thank Dan Gough, former Colgate University Associate Vice President

448 for Campus Safety, and Environmental Health, and Emergency Management for assistance in 449 initiating the project, and in procuring the wastewater sample collection devices. The authors

450 are also grateful to Jim Albertina and the Colgate University Plumbing Department for their 451 assistance in identifying, establishing, and maintaining wastewater sampling locations. We

452 thank Karen Cheal, Neal Albert, and the office of Institutional Planning and Research for 453 providing student housing data. We also thank Bineyam Taye and David Larsen for their 454 thoughtful review of the manuscript. The authors are extremely grateful to the employees in 455 Student Health Services, as well as the student and other volunteers who worked tirelessly in 456 collecting student and employee patient samples throughout the year. Finally, the authors are 457 extremely grateful to the Colgate University Health Analytics Team, especially Sev Flanigen, Tim 458 Borfitz, and Mary Williams, for their work on behalf of the university, and for their thoughtful 459 and productive analysis on the use of wastewater surveillance data to manage Colgate's COVID46019 pandemic response. This project was funded entirely by Colgate University.

462 References.

463 1. Xiao F, Tang M, Zheng X, Liu Y, Li X, Shan H. 2020. Evidence for Gastrointestinal Infection of SARS-CoV-2. Gastroenterology2020/03/03. 158:1831-1833.e3. 
medRxiv preprint doi: https://doi.org/10.1101/2021.09.15.21263338; this version posted September 22, 2021. The copyright holder for this

preprint (which was not certified by peer review) is the author/funder, who has granted medRxiv a license to display the preprint in perpetuity.

It is made available under a CC-BY-NC-ND 4.0 International license .

465 2. Lee S, Yoon GY, Myoung J, Kim S-J, Ahn D-G. 2020. Robust and persistent SARS-CoV-2 infection in the human intestinal brush border expressing cells. Emerg Microbes Infect 9:2169-2179.

468 3. Chen Y, Chen L, Deng Q, Zhang G, Wu K, Ni L, Yang Y, Liu B, Wang W, Wei C, Yang J, Ye 469 G, Cheng Z. 2020. The presence of SARS-CoV-2 RNA in the feces of COVID-19 patients. J $470 \quad$ Med Virol 92:833-840.

471 4. Zhang Y, Chen C, Song Y, Zhu S, Wang D, Zhang H, Han G, Weng Y, Xu J, Xu J, Yu P, Jiang 472 W, Yang X, Lang Z, Yan D, Wang Y, Song J, Gao GF, Wu G, Xu W. 2020. Excretion of SARS473 CoV-2 through faecal specimens. Emerg Microbes Infect 9:2501-2508.

474 5. Tang A, Tong Z-D, Wang H-L, Dai Y-X, Li K-F, Liu J-N, Wu W-J, Yuan C, Yu M-L, Li P, Yan J475 B. 2020. Detection of Novel Coronavirus by RT-PCR in Stool Specimen from 476 Asymptomatic Child, China. Emerg Infect Dis2020/06/17. 26:1337-1339.

477 6. Santiso-Bellón C, Randazzo W, Pérez-Cataluña A, Vila-Vicent S, Gozalbo-Rovira R, 478 Muñoz C, Buesa J, Sanchez G, Rodríguez Díaz J. 2020. Epidemiological Surveillance of 479 Norovirus and Rotavirus in Sewage (2016-2017) in Valencia (Spain). Microorganisms $480 \quad 8: 458$.

481 7. Lodder WJ, Buisman AM, Rutjes SA, Heijne JC, Teunis PF, de Roda Husman AM. 2012.

482 Feasibility of quantitative environmental surveillance in poliovirus eradication strategies. $483 \quad$ Appl Environ Microbiol2012/03/23. 78:3800-3805.

484 8. Zurbriggen S, Tobler K, Abril C, Diedrich S, Ackermann M, Pallansch MA, Metzler A.

9. Sims N, Kasprzyk-Hordern B. 2020. Future perspectives of wastewater-based epidemiology: Monitoring infectious disease spread and resistance to the community

490 10. Nemudryi A, Nemudraia A, Wiegand T, Surya K, Buyukyoruk M, Cicha C, Vanderwood KK, Wilkinson R, Wiedenheft B. 2020. Temporal Detection and Phylogenetic Assessment of SARS-CoV-2 in Municipal Wastewater. Cell Reports Med 1:100098.

11. Wu F, Zhang J, Xiao A, Gu X, Lee WL, Armas F, Kauffman K, Hanage W, Matus M, Ghaeli 
N, Endo N, Duvallet C, Poyet M, Moniz K, Washburne AD, Erickson TB, Chai PR,

Thompson J, Alm EJ. 2020. SARS-CoV-2 Titers in Wastewater Are Higher than Expected from Clinically Confirmed Cases. mSystems 5:e00614-20.

12. Weidhaas J, Aanderud ZT, Roper DK, VanDerslice J, Gaddis EB, Ostermiller J, Hoffman K, Jamal R, Heck P, Zhang Y, Torgersen K, Laan J Vander, LaCross N. 2021. Correlation of SARS-CoV-2 RNA in wastewater with COVID-19 disease burden in sewersheds. Sci Total Environ2021/02/12. 775:145790.

13. Peccia J, Zulli A, Brackney DE, Grubaugh ND, Kaplan EH, Casanovas-Massana A, Ko AI, Malik AA, Wang D, Wang M, Warren JL, Weinberger DM, Arnold W, Omer SB. 2020. Measurement of SARS-CoV-2 RNA in wastewater tracks community infection dynamics. Nat Biotechnol 38:1164-1167.

14. Randazzo W, Truchado P, Cuevas-Ferrando E, Simón P, Allende A, Sánchez G. 2020. SARS-CoV-2 RNA in wastewater anticipated COVID-19 occurrence in a low prevalence area. Water Res 181:115942.

15. Medema G, Heijnen L, Elsinga G, Italiaander R, Brouwer A. 2020. Presence of SARS-

16. Karthikeyan S, Nguyen A, McDonald D, Zong Y, Ronquillo N, Ren J, Zou J, Farmer S, Coronavirus-2 RNA in Sewage and Correlation with Reported COVID-19 Prevalence in the Knight R, McGrath J. 2021. Rapid, Large-Scale Wastewater Surveillance and Automated

517 17. Scott LC, Aubee A, Babahaji L, Vigil K, Tims S, Aw TG. 2021. Targeted wastewater surveillance of SARS-CoV-2 on a university campus for COVID-19 outbreak detection and mitigation. Environ Res 200:111374. 
surveillance on a university campus. Sci Total Environ2021/03/30. 782:146749.

524 19. Harris-Lovett S, Nelson KL, Beamer P, Bischel HN, Bivins A, Bruder A, Butler C,

525 Camenisch TD, De Long SK, Karthikeyan S, Larsen DA, Meierdiercks K, Mouser PJ,

SARS-CoV-2 on College Campuses: Initial Efforts, Lessons Learned, and Research Needs. Int J Environ Res Public Heal .

20. Sharkey ME, Kumar N, Mantero AMA, Babler KM, Boone MM, Cardentey Y, Cortizas EM, Grills GS, Herrin J, Kemper JM, Kenney R, Kobetz E, Laine J, Lamar WE, Mader CC, Mason CE, Quintero AZ, Reding BD, Roca MA, Ryon K, Solle NS, Schürer SC, Shukla B, Solo-Gabriele HM. 2021. Lessons learned from SARS-CoV-2 measurements in wastewater. Sci Total Environ 798:149177.

536 21. Betancourt WQ, Schmitz BW, Innes GK, Prasek SM, Pogreba Brown KM, Stark ER, Foster AR, Sprissler RS, Harris DT, Sherchan SP, Gerba CP, Pepper IL. 2021. COVID-19 containment on a college campus via wastewater-based epidemiology, targeted clinical testing and an intervention. Sci Total Environ2021/03/13. 779:146408.

22. Wilder ML, Middleton F, Larsen DA, Du Q, Fenty A, Zeng T, Insaf T, Kilaru P, Collins M, Kmush B, Green HC. 2021. Co-quantification of crAssphage increases confidence in

544 23. Jones DL, Baluja MQ, Graham DW, Corbishley A, McDonald JE, Malham SK, Hillary LS, Connor TR, Gaze WH, Moura IB, Wilcox MH, Farkas K. 2020. Shedding of SARS-CoV-2 in feces and urine and its potential role in person-to-person transmission and the

$549 \quad$ Figure Legends.

551 Figure 1. Location of wastewater sample collection points on the Colgate University campus. 
medRxiv preprint doi: https://doi.org/10.1101/2021.09.15.21263338; this version posted September 22, 2021. The copyright holder for this preprint (which was not certified by peer review) is the author/funder, who has granted medRxiv a license to display the preprint in perpetuity.

It is made available under a CC-BY-NC-ND 4.0 International license .

552 Locations 1-5 were at sewer access holes, while locations 6-7 were at wastewater lift stations.

553 Colored lines indicate approximate location of sewage drains from each residence.

555 Figure 2. Aggregate wastewater and patient case data at Colgate University, August 2020-May 2021.

556 Normalized SARS-CoV-2 RNA levels in wastewater (black symbols; left Y-axis) and number of positive

557 student cases (gray bars; right Y-axis) are shown from the fall semester 2020 (A) and spring semester

5582021 (B). Symbol shapes represent individual sampling locations and associated residence halls, as

559 indicated in the legend.

561 Figure 3. The relative level of SARS-CoV-2 RNA in positive SARS-CoV-2 clinical cases, but not the

562 levels of wastewater RNA, were significantly higher in the spring semester. The data points

563 represent the average $\mathrm{Ct}$ value from positive cases (A) and the normalized level of SARS-CoV-2 RNA

564 levels in positive wastewater samples (B). ${ }^{* * *}, p<0.0001$ by Welch's $t$ test. $n s, p>0.05$ of log

565 transformed data by Welch's $\mathrm{t}$ test.

567 Figure 4. Aggregate wastewater and patient case data for sampled sewersheds, Colgate

568 University, August 2020 - May 2021. Normalized SARS-CoV-2 RNA levels in wastewater (black

569 circles; left $\mathrm{Y}$-axis) and average $\mathrm{Ct}$ values of positive cases (red circles; right $\mathrm{Y}$-axis) are shown from

570 each wastewater sampling location. Red stars indicate positive student tests for which no $\mathrm{Ct}$ value

571 was available. Yellow and green squares represent the time of isolation start (when individual

572 student cases were removed from the indicated residences) and the time of return to the residence

573 following isolation, respectively.

575 Figure 5. Temporal association of SARS-CoV-2 levels in wastewater RNA and Ct values of positive

576 cases. Data from individual wastewater SARS-CoV-2 RNA samples and positive SARS-CoV-2 cases

577 were classified according to the indicated temporal relationships. A. The number of positive

578 wastewater samples according to temporal category, with respect to positive case in the residences

579 contributing to the waste stream. B. The relative wastewater SARS-CoV-2 level according to

580 temporal category, with respect to positive case(s) in residences contributing to the waste stream. C. 
medRxiv preprint doi: https://doi.org/10.1101/2021.09.15.21263338; this version posted September 22, 2021. The copyright holder for this preprint (which was not certified by peer review) is the author/funder, who has granted medRxiv a license to display the preprint in perpetuity. It is made available under a CC-BY-NC-ND 4.0 International license.

581 The relative wastewater SARS-CoV-2 level according to the number of clinical cases identified in 582 residences contributing to the waste stream at the time of collection. D. The relative Ct value of 583 positive case(s) according to temporal category, with respect to positive detection(s) of SARS-CoV-2

584 in the waste stream. Data represent total number of samples (a) or a box and whisker plot indicating 585 the 5th and 95th percentile $(B, C)$. ${ }^{* * *}, p<0.001$ by Kruskal-Wallis test, with Dunn's multiple 586 comparison. 
medRxiv preprint doi: https://doi.org/10.1101/2021.09.15.21263338; this version posted September 22, 2021. The copyright holder for this preprint (which was not certified by peer review) is the author/funder, who has granted medRxiv a license to display the preprint in perpetuity.

It is made available under a CC-BY-NC-ND 4.0 International license .

Table 1. Student population, cases, and positive wastewater samples at Colgate University, Fall 2020-Spring 2021.

\begin{tabular}{|c|c|c|c|c|c|c|}
\hline Sampling Locations & $\begin{array}{c}\text { Fall } \\
\text { Population } \\
\end{array}$ & $\begin{array}{c}\text { Spring } \\
\text { Population } \\
\end{array}$ & Fall Cases & Spring Cases & $\begin{array}{l}\text { Fall Positive } \\
\text { WW samples } \\
\end{array}$ & \begin{tabular}{|c|} 
Spring \\
Positive WW \\
samples \\
\end{tabular} \\
\hline GH/BAE & 336 & 336 & 4 & 7 & 4 & 7 \\
\hline SWP & 289 & 269 & 3 & 5 & 3 & 5 \\
\hline$C D$ & 338 & 330 & 6 & 13 & 0 & 13 \\
\hline$B C$ & 370 & 365 & 5 & 6 & 2 & 2 \\
\hline $\mathrm{PL}$ & 162 & 160 & 7 & 5 & 2 & 12 \\
\hline $\mathrm{TH}$ & 219 & 212 & 6 & 12 & 1 & 9 \\
\hline $\begin{array}{l}\text { Total Student Population/Cases in } \\
\text { Sampled Residences (percent of total) }\end{array}$ & $1714(73.5 \%)$ & $\begin{array}{c}1672 \\
(73.3 \%) \\
\end{array}$ & $31(70.5 \%)$ & $\begin{array}{c}48 \\
(76.2 \%) \\
\end{array}$ & & \\
\hline $\begin{array}{l}\text { Total Student Population/Cases in } \\
\text { Non-Sampled Campus Residences }\end{array}$ & $619(26.5 \%)$ & $608(26.7 \%)$ & $\begin{array}{c}13 \\
(29.5 \%)\end{array}$ & $\begin{array}{c}15 \\
(23.8 \%)\end{array}$ & & \\
\hline Total & 2333 & 2280 & 44 & 63 & & \\
\hline
\end{tabular}

Table 2. Performance of SARS-CoV-2 wastewater testing (within $<7$ days pre-case identification to 14 days post return from isolation) in predicting human cases at Colgate University, Fall 2020-Spring 2021

\begin{tabular}{|l|c|c|c|}
\hline & $\begin{array}{c}\text { Student case(s) } \\
\text { in the sampled } \\
\text { residence }\end{array}$ & $\begin{array}{c}\text { No student } \\
\text { case(s) in the } \\
\text { sampled } \\
\text { residence }\end{array}$ & \\
\hline $\begin{array}{l}\text { Positive wastewater sample (from within }<7 \\
\text { days pre-case identification to }<14 \text { days } \\
\text { post-return from isolation }\end{array}$ & 46 & 12 & PPV: $\mathbf{7 9 . 3 1 \%}$ \\
\hline $\begin{array}{l}\text { Negative wastewater sample (from within } \\
\text { <7 days pre-case identification to }<14 \text { days } \\
\text { post-return from isolation }\end{array}$ & 120 & 230 & NPV: $\mathbf{6 5 . 7 1 \%}$ \\
\hline & $\begin{array}{c}\text { Sensitivity: } \\
\mathbf{2 7 . 7 1 \%}\end{array}$ & & \\
\hline Chi-square value 48.1, Df $\mathbf{= 1 ,} \mathbf{p}<\mathbf{0 . 0 0 1}$ & $\begin{array}{c}\text { Specificity: } \\
\mathbf{9 5 . 0 4 \%}\end{array}$ & & \\
\hline
\end{tabular}

Table 3. Performance of SARS-CoV-2 wastewater testing (within $<7$ days pre-case identification) in predicting human cases at Colgate University, Fall 2020-Spring 2021

\begin{tabular}{|c|c|c|c|}
\hline & $\begin{array}{c}\text { Student case(s) } \\
\text { in the sampled } \\
\text { residence }\end{array}$ & $\begin{array}{l}\text { No student } \\
\text { case }(\mathrm{s}) \text { in the } \\
\text { sampled } \\
\text { residence }\end{array}$ & \\
\hline $\begin{array}{l}\text { Positive wastewater sample (from within }<7 \\
\text { days pre-case identification) }\end{array}$ & 14 & 12 & PPV: $53.85 \%$ \\
\hline $\begin{array}{l}\text { Negative wastewater sample (from within } \\
<7 \text { days pre-case identification) }\end{array}$ & 10 & 230 & NPV: $95.83 \%$ \\
\hline & $\begin{array}{l}\text { Sensitivity: } \\
58.33 \%\end{array}$ & & \\
\hline Chi-square value 64.61, Df $=1, p<0.001$ & $\begin{array}{l}\text { Specificity: } \\
95.04 \%\end{array}$ & & \\
\hline
\end{tabular}


medRxiv preprint doi: https://doi.org/10.1101/2021.09.15.21263338; this version posted September 22, 2021. The copyright holder for this preprint (which was not certified by peer review) is the author/funder, who has granted medRxiv a license to display the preprint in perpetuity.

It is made available under a CC-BY-NC-ND 4.0 International license .

1. Gate House (GH)

2. Burke/Andrews/East (BAE)

3. Stillman/West/Pinchin (SWP)

4. Curtis/Drake

5. Bryan/113 Broad

6. Parker Lift Station (PL)

7. Townhouses $(\mathrm{TH})$
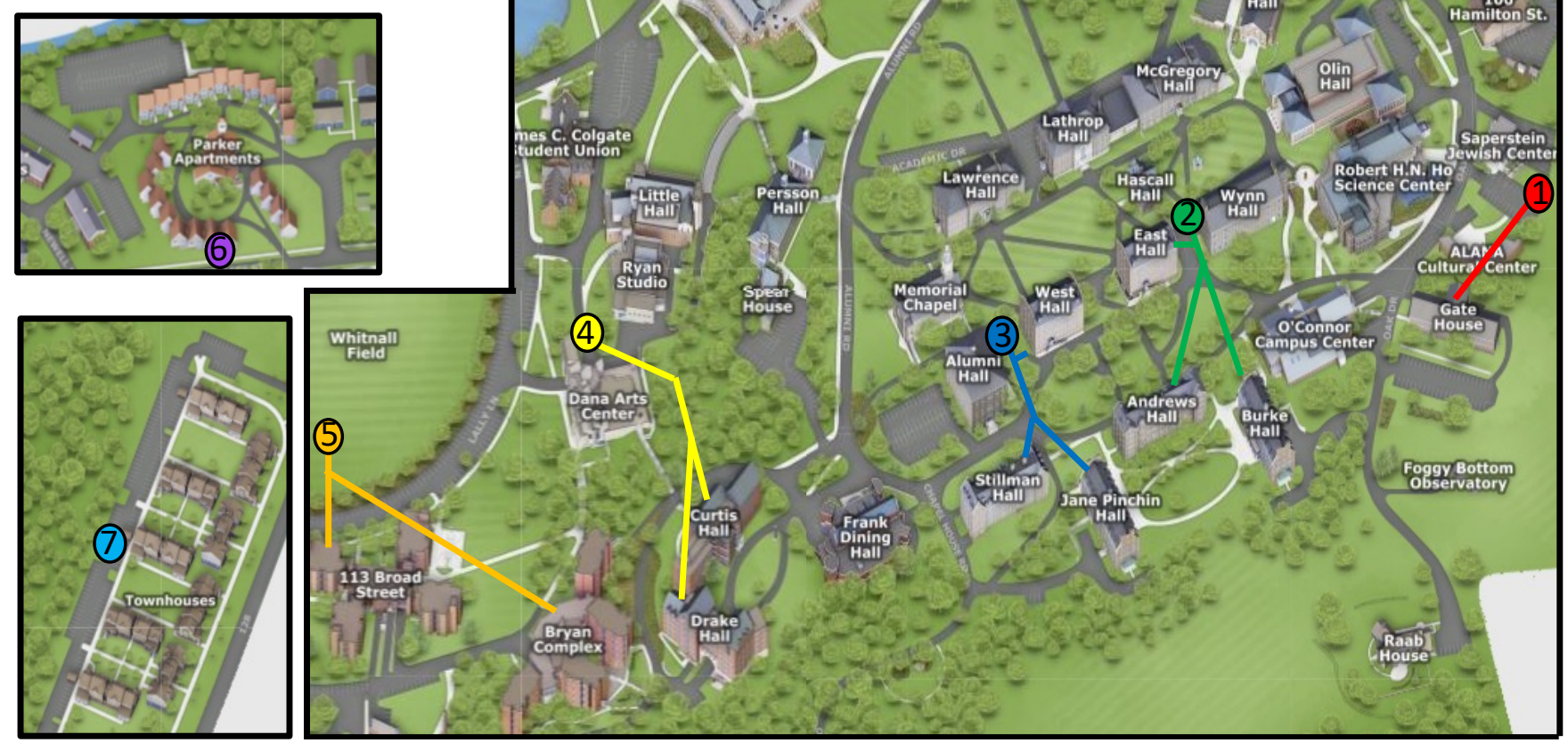

Figure 1. Location of wastewater sample collection points on the Colgate University campus. Locations 1-5 were at sewer access holes, while locations 6-7 were at wastewater lift stations. Colored lines indicate approximate location of sewage drains from each residence. 
medRxiv preprint doi: https://doi.org/10.1101/2021.09.15.21263338; this version posted September 22, 2021. The copyright holder for this preprint (which was not certified by peer review) is the author/funder, who has granted medRxiv a license to display the preprint in perpetuity.

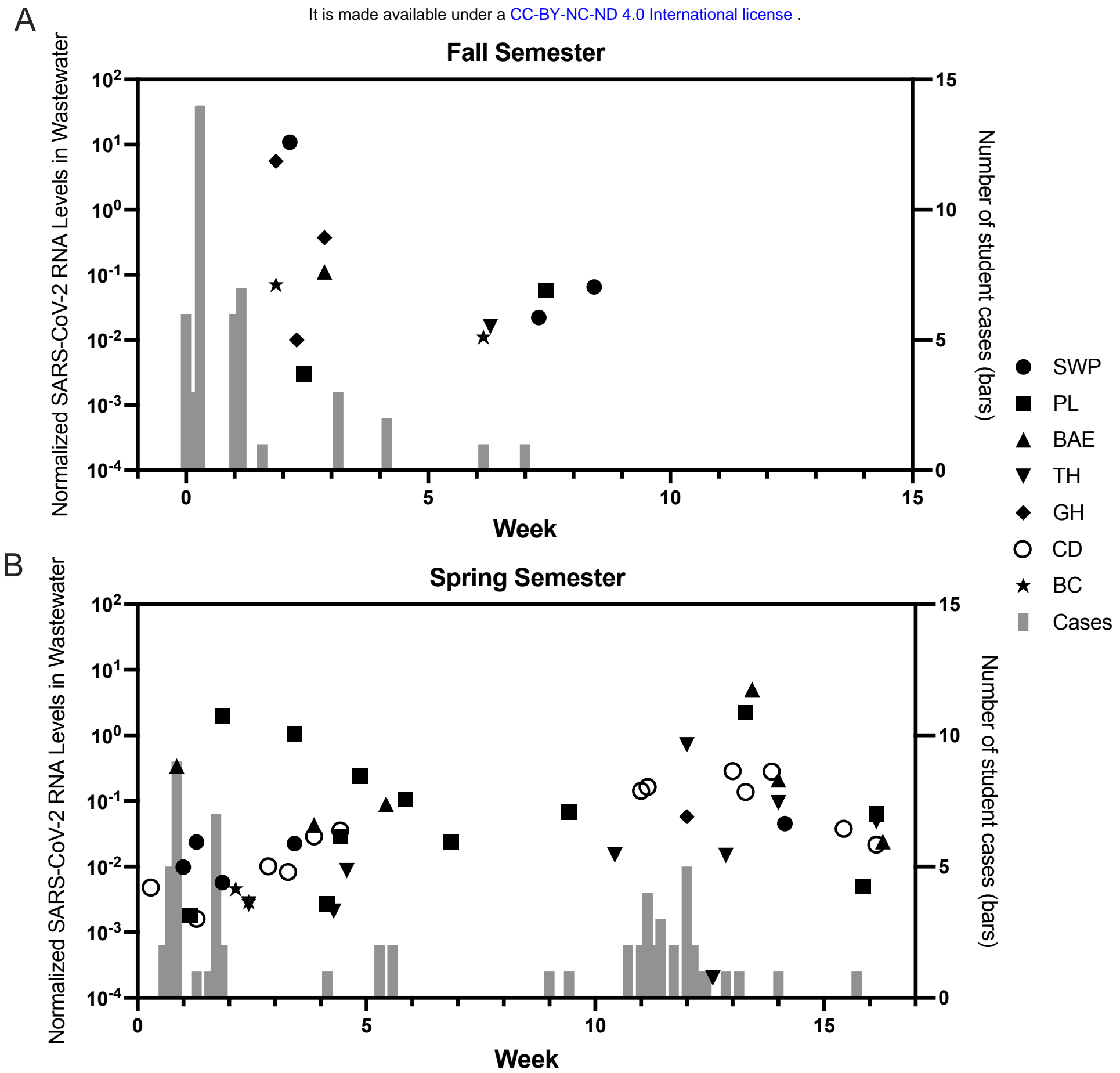

Figure 2. Aggregate wastewater and patient case data at Colgate University, August 2020May 2021. Normalized SARS-CoV-2 RNA levels in wastewater (black symbols; left Y-axis) and number of positive student cases (gray bars; right Y-axis) are shown from the fall semester 2020 (A) and spring semester 2021 (B). Symbol shapes represent individual sampling locations and associated residence halls, as indicated in the legend. 

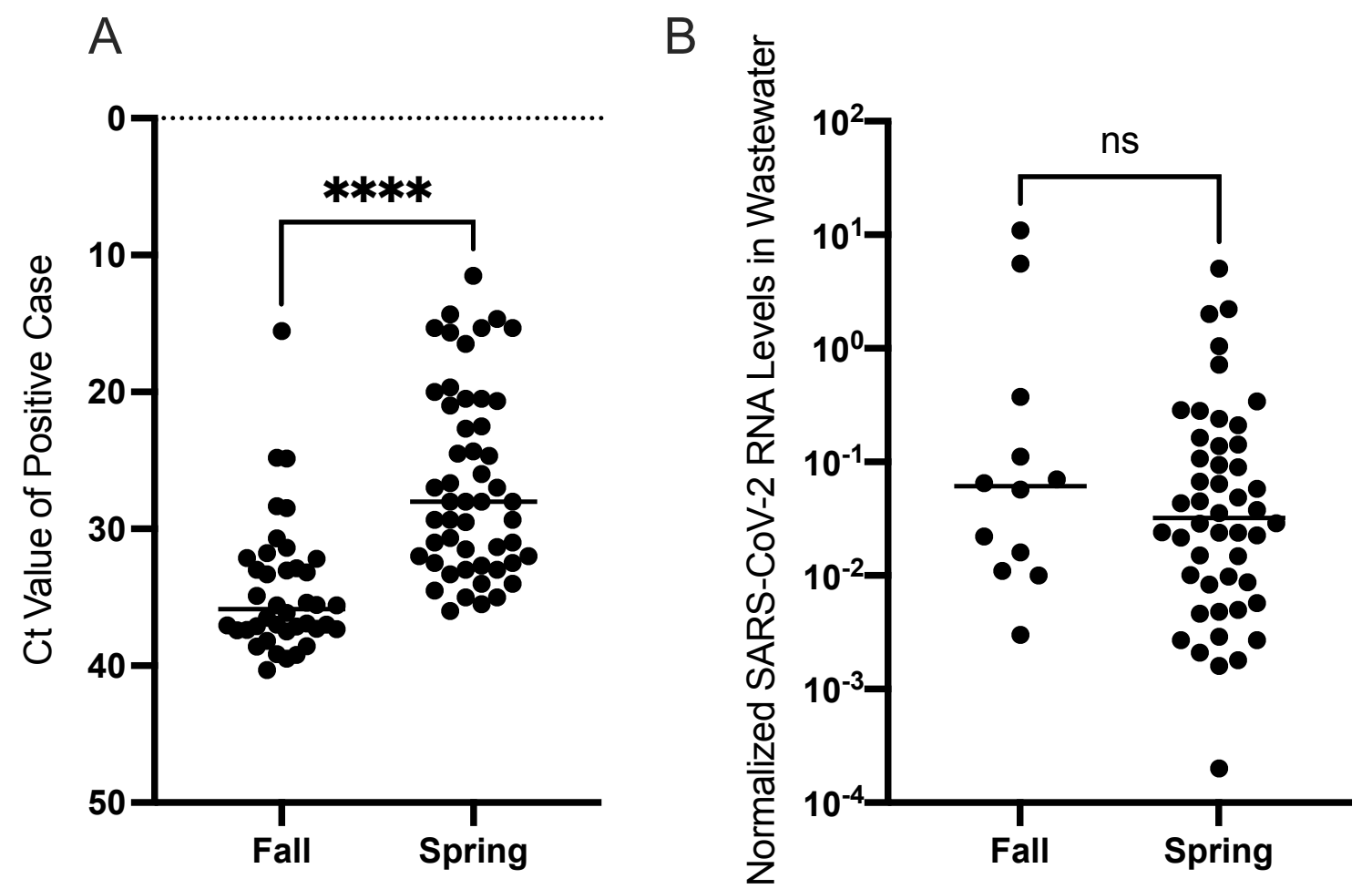

Figure 3. The relative level of SARS-CoV-2 RNA in positive SARS-CoV-2 clinical cases, but not the levels of wastewater RNA, were significantly higher in the spring semester. The data points represent the average Ct value from positive cases (A) and the normalized level of SARS-CoV-2 RNA levels in positive wastewater samples $(\mathrm{B}){ }^{* * * *}, p<0.0001$ by Welch's t test. ns, $p>$ 0.05 of log transformed data by Welch's t test. 
medRxiv preprint doi: https://doi.org/10.1101/2021.09.15.21263338; this version posted September 22, 2021. The copyright holder for this preprint (which was not certified by peer review) is the author/funder, who has granted medRxiv a license to display the preprint in perpetuity.

It is made available under a CC-BY-NC-ND 4.0 International license .

A
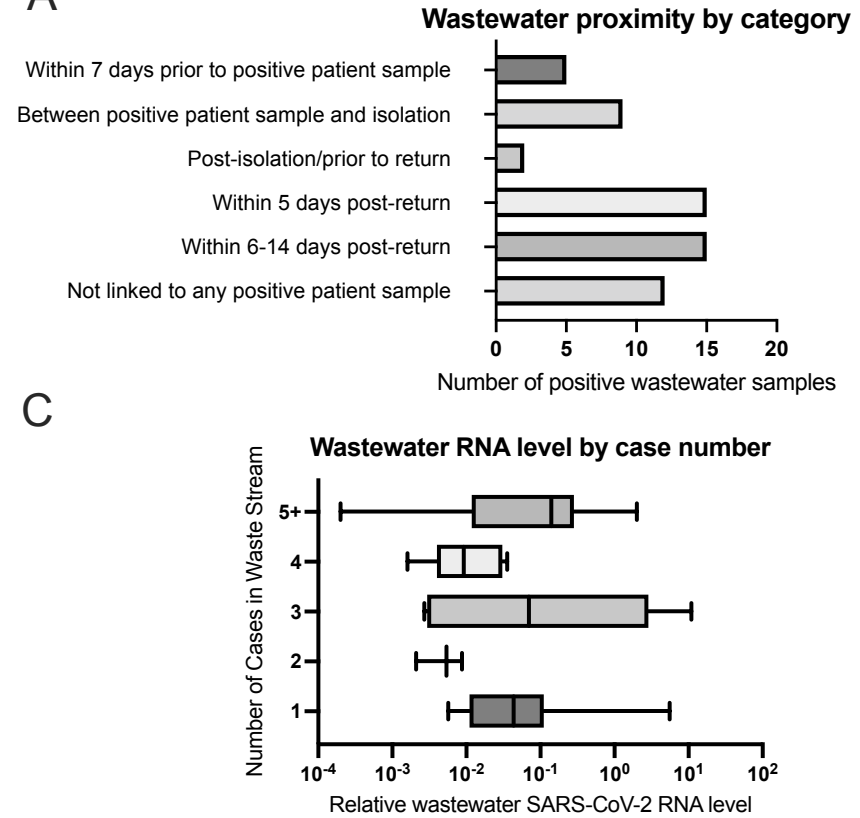

B

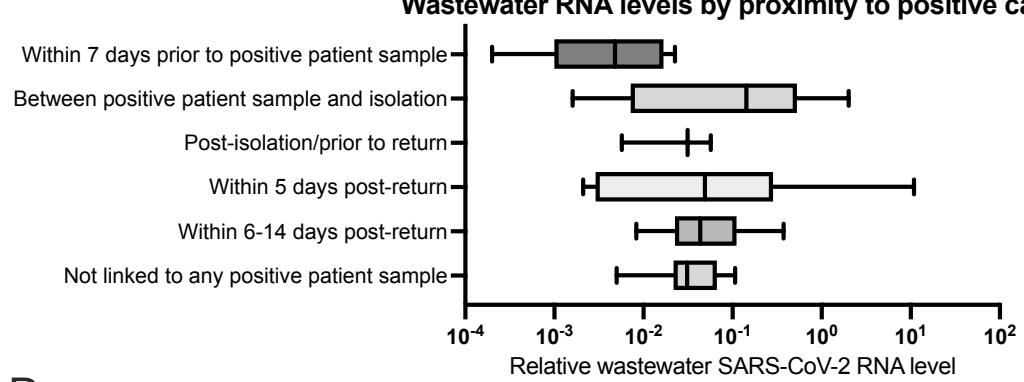

$\mathrm{D}$

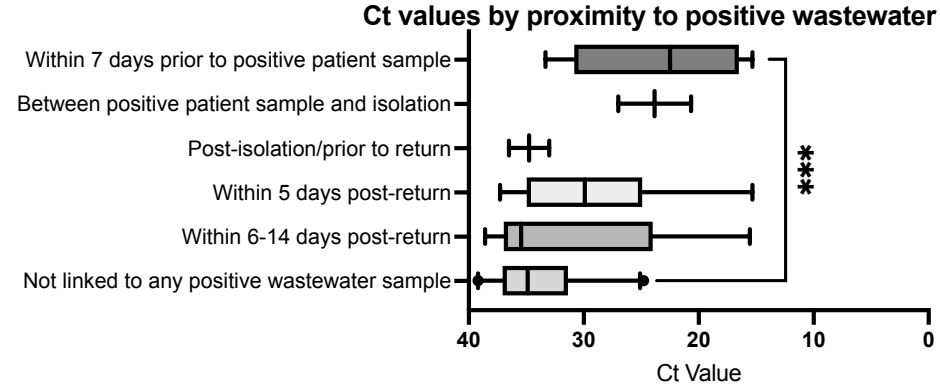

Figure 5. Temporal association of SARS-CoV-2 levels in wastewater RNA and Ct values of positive cases. Data from individual wastewater SARS-CoV-2 RNA samples and positive SARS-CoV-2 cases were classified according to the indicated temporal relationships. A. The number of positive wastewater samples according to temporal category, with respect to positive case in the residences contributing to the waste stream. B. The relative wastewater SARSCoV-2 level according to temporal category, with respect to positive case(s) in residences contributing to the waste stream. C. The relative wastewater SARS-CoV-2 level according to the number of clinical cases identified in residences contributing to the waste stream at the time of collection. D. The relative Ct value of positive case(s) according to temporal category, with respect to positive detection(s) of SARS-CoV-2 in the waste stream. Data represent total number of samples (a) or a box and whisker plot indicating the 5th and 95th percentile $(B, C) .{ }^{* * *}, p<0.001$ by KruskalWallis test, with Dunn's multiple comparison. 